\title{
EFEKTIVITAS LAYANAN INFORMASI DENGAN MENGGUNAKAN STRATEGI COOPERATIVE LEARNING UNTUK MENINGKATKAN PEMAHAMAN SISWA MENGENAI BAHAYA SEKS BEBAS
}

\author{
Eko Sujadi $^{1}$, Yesi Noviani ${ }^{2}$ \\ 1,2,3,4 Institut Agama Islam Negeri (LAIN) Kerinci \\ e-mail: ekosujadi91@gmail.com
}

\begin{abstract}
School is a place where students can develop positive and negative understandings, one of which is the danger of free sex. The purpose of this study is to improve students' understanding of the dangers of free sex through the application of information services using cooperative learning strategies. The approach of this research is quantitative. The population in this study were the eighth grade students of 26 Kerinci State Middle School as many as 23 students. Data collection is obtained using a Likert scale. The data analysis technique used is the Wilcoxon Signed Rank. Test. The findings of this study are there are differences in students' understanding of the dangers of free sex to students before being given treatment (pretest) and after being given treatment (Posttest) in the form of Information Services using Cooperative Learning Strategies.
\end{abstract}

Keywords: Information Services, Cooperative Learning, Danger of Free Sex.

\begin{abstract}
Abstrak. Sekolah merupakan tempat dimana siswa dapat mengembangkan pemahaman yang positif maupun negatif, salah satunya mengenai bahaya seks bebas. Tujuan dari penelitian ini adalah untuk meningkatkan pemahaman siswa mengenai bahaya seks bebas melalui penerapan layanan informasi dengan menggunakan strategi cooperative learning. Pendekatan penelitian ini adalah kuantitatif. Populasi pada penelitian ini adalah siswa kelas VIII SMP Negeri 26 Kerinci sebanyak 23 siswa. Pengumpulan datanya diperoleh dengan menggunakan skala likert. Teknik analisa data yang digunakan yakni Wilcoxon Signed Rank Test. Adapun temuan penelitian ini adalah terdapat perbedaan pemahaman Siswa mengenai bahaya seks bebas kepada siswa sebelum diberikan perlakuan (Pretest) dan sesudah diberikan perlakuan (Posttest) berupa Layanan Informasi dengan mengunakan Strategi Cooperative Learning.
\end{abstract}

Kata Kunci: Layanan Informasi, Cooperative Learning, Bahaya Seks Bebas. 


\section{PENDAHULUAN}

Kegiatan pendidikan pada dasarnya telah berjalan sejalan manusia itu ada. Upayaupaya pendidikan dilakukan dalam rangka memberikan kemampuan kepada manusia untuk dapat hidup mandiri dan hidup bersama ditengah-tengah masyarakat. Dewasa ini pendidikan mengalami banyak perbaikan demi terwujudnya cita-cita dan tujuan dari pendidikan itu sendiri.

Pendidikan merupakan aspek yang sangat penting untuk menunjang kehidupan seseorang. Melalui pendidikan maka potensi-potensi dasar yang dimiliki oleh individu dapat berkembang dengan baik. Tentunya pendidikan yang diselenggarakan merupakan program yang dilaksanakan dengan memanfaatkan ilmu pendidikan itu sendiri, sehingga pelaksanaanya sesuai dengan kaidah-kaidah kebenaran dan mengarah pada terbentuknya kedirian dan individu yang positif.

Hal ini juga tertera dalam Undang-Undang No. 20 tahun 2003 tentang Sistem Pendidikan Nasional, pasal 1 ayat 1 dijelaskan bahwa "Pendidikan adalah usaha sadar dan terencana untuk mewujudkan suasana belajar dalam proses pembelajaran agar peserta didik secara aktif mengembangkan potensi dirinya untuk memiliki kekuatan spritual keagamaan, pengendalian diri, kepribadian, kecerdasan, akhlak mulia, serta ketrampilan yang diperlukan dirinya, Bangsa dan Negara. Menyikapi amanat UU No.20 tahun 2003 ini, maka salah satu upaya mengembangkan potensi diri siswa adalah melalui penyelenggaraan kegiatan bimbingan dan konseling di sekolah.

Namun, salah satu masalah yang sering terjadi di sekolah adalah lemahnya pelaksanaan layanan bimbingan dan konseling itu sendiri, padahal bimbingan dan konseling merupakan suatu hal yang sangat penting guna membantu para siswa yang berada dalam usia remaja untuk mendapatkan suatu informasi dan menyelesaikan masalahnya. Remaja dimaknai sebagai masa perkembangan transisi antara masa anak dan masa dewasa yang mencakup perubahan biologis, kognitif, dan sosial-emosional. Salah satu permasalahan yang terjadi pada remaja yakni berkaitan dengan tingkat kematangan seksualnya. Bagi remaja yang bisa mengendalikan dorongan seksual, maka remaja akan terhindar dari perilaku seksual yang menyimpang, sebaliknya apabila remaja tidak bisa mengendalikannya maka remaja akan terjerumus kedalam perilaku seks bebas.

Perilaku seks bebas adalah aktifitas seksual yang dilakukan di luar perkawinan yang sama dengan zina, dan segala cara mengekspresikan dan melepaskan dorongan seksual yang berasal dari kematangan organ seksual, bercumbu, sampai melakukan kontak seksual yang dinilai tidak sesuai dengan norma. Nurhidayati \& Pratiwi (2013) mendefinisikan perilaku seks 
bebas sebagai segala tingkah laku yang didorong oleh hasrat seksual baik dengan lawan jenis maupun sesama jenis mulai dari tingkah laku yang dilakukannya dengan sentuhan, berciuman.

Berdasarkan wawancara yang dilakukan oleh peneliti terhadap guru BK, peneliti mendapatkan informasi bahwa terdapat beberapa peserta didik yang menyimpan video porno. Siswa yang menyimpan video porno itu mendapatkan sanksi dari sekolah yaitu handphone siswa tersebut ditahan, diberi skor selama 1 minggu serta harus mematuhi kode etik yang berlaku di sekolah.

Berdasarkan hal di atas Guru BK khawatir terhadap siswanya yang masih belum memahami bahaya seks bebas. Dikhawatirkan siswa terjerat dalam pergaulan yang tidak bertanggung jawab yang akan merusak masa depannya. Remaja biasanya melakukan segala sesuatu tanpa berpikir sehingga dapat membawa dampak buruk bagi dirinya maupun keluarganya. Masalah lain seperti adanya siswa-siswi yang berpacaran, dan siswa laki-laki melakukan seperti pelecehan seksual kepada lawan jenis dan permasalahan lainnya.

Perilaku seks bebas ini selain telah mengabaikan norma, juga telah mendorong terjadinya pergeseran fungsi utama seks bagi manusia. Salah satu layanan dalam bimbingan dan konseling yang dapat digunakan untuk mencegah terjadinya seks bebas adalah layanan informasi. Beberapa hasil penelitian telah membuktikan hal tersebut (Susanto, 2015; Fitriyah, 2016; Hendrik \& Ratini, 2018).

Layanan informasi adalah layanan bimbingan dan konseling yang memungkinkan peserta didik (klien) menerima dan memahami berbagai informasi yang dapat digunakan sebagai bahan pertimbangan dan pengambilan keputusan untuk kepentingan peserta didik (klien) Klien tidak hanya peserta didik tetapi bisa juga orang tua atau wali (Hallen, 2005).

Layanan ini bertujuan untuk membekali individu dengan berbagi pengetahuan dan pemahaman tentang berbagai hal yang berguna untuk mengenal diri, merencanakan, dan mengembangkan pola kehidupan sebagai pelajar, anggota keluarga dan masyarakat. Pemahaman yang diperoleh melalui layanan informasi, digunakan sebagai bahan acuan dalam meningkatkan kegiatan dan prestasi belajar, mengembangkan cita-cita, menyelenggarakan kehidupan sehari-hari dalam mengambil sebuah keputusan. Layanan informasi dapat dilaksanakan melalui beragam strategi dan metode, seperti strategi cooperative learning.

Cooperative learning adalah suatu strategi pembelajaran yang menekankan pada sikap atau perlaku bersama dalam bekerja atau membantu di antara sesama dalam struktur kerjasama yang teratur dalam kelompok, yang terdiri dari dua orang atau lebih (Syarifuddin, 2011). Dimana pada tiap kelompok tersebut terdiri dari siswa-siswa berbagai tingkat kemampuan, melakukan berbagai kegiatan belajar untuk meningkatkan pemahaman mereka tentang materi 
pelajaran yang sedang dipelajari. Setiap anggota kelompok bertanggung jawab untuk tidak hanya belajar apa yang diajarkan tetapi juga untuk membantu rekan belajar, sehingga bersamasama mencapai keberhasilan. Semua Siswa berusaha sampai semua anggota kelompok berhasil memahami dan melengkapinya.

Berdasarkan latar belakang di atas, peneliti ingin mengetahui efektivitas layanan Penerapan Layanan Informasi dengan mengunakan Strategi Cooperative Learning untuk Meningkatkan Pemahaman Siswa Mengenai Bahaya Seks Bebas.

\section{METODE}

Penelitian ini menggunakan pendekatan kuantitatif. Jenis penelitian yang digunakan adalah Eksperimen One Group Pretest-posttest Design. Populasi dalam penelitian ini adalah seluruh siswa kelas VIII yang berjumlah 23 orang di SMPN 26 Kerinci. Di karenakan populasi kurang dari 100 orang, maka peneliti menggunakan seluruh populasi untuk di jadikan sampel. Teknik pengumpulan data yang digunakan dalam penelitian ini berupa kuesioner. Kuesioner yang digunakan untuk memperoleh gambaran tentang pemahaman bahaya seks bebas dalam penelitian yang dikembangkan sendiri oleh peneliti dengan model skala Likert. Teknik analisa data untuk mengetahui Efektivitas Penerapan Layanan Informasi Dengan Mengunakan Strategi Cooperative Learning Untuk Meningkatkan Pemahaman Siswa Mengenai Bahaya Seks Bebas digunakan rumus Uji Wilcoxon.

\section{HASIL}

Berdasarkan data yang diperoleh, maka dapat dideskripsikan hasil penelitian sebelum dilakukan perlakuan (Pretest) dan sesudah diberikan perlakuan (Posttest). Dimana pengolahan data kuantitatif dilakukan dengan menggunakan bantuan SPSS versi 17.0 for windows.

\section{Deskripsi Data Pretest}

Sesuai dengan tujuan dilakukannya pretest, yaitu untuk mengetahui gambaran awal kondisi pemahaman Siswa mengenai bahaya seks bebas. Maka dapat dilihat dalam data hasil Pretest pada tabel dibawah ini: 
Tabel 1. Data Hasil Pretest Pemahaman Siswa Mengenai Bahaya Seks Bebas.

\begin{tabular}{|c|c|c|c|}
\hline Kategori & Rentang Skor & Frekuensi & Persentase \\
\hline Sangat Rendah & $\leq 42$ & 0 & 0 \\
\hline Rendah & $42>$ s.d $\leq 56$ & 7 & 30.43 \\
\hline Sedang & $56>$ s.d $\leq 69$ & 8 & 34.79 \\
\hline Tinggi & $69>$ s.d $\leq 83$ & 6 & 26.08 \\
\hline Sangat Tinggi & $83>$ & 2 & 8.7 \\
\hline \multicolumn{2}{|c|}{ Jumlah } & 23 & 100 \\
\hline
\end{tabular}

Berdasarkan tabel data hasil pretes rata pemahaman Siswa mengenai bahaya seks bebas dapat digambarkan dalam diagram dibawah ini:

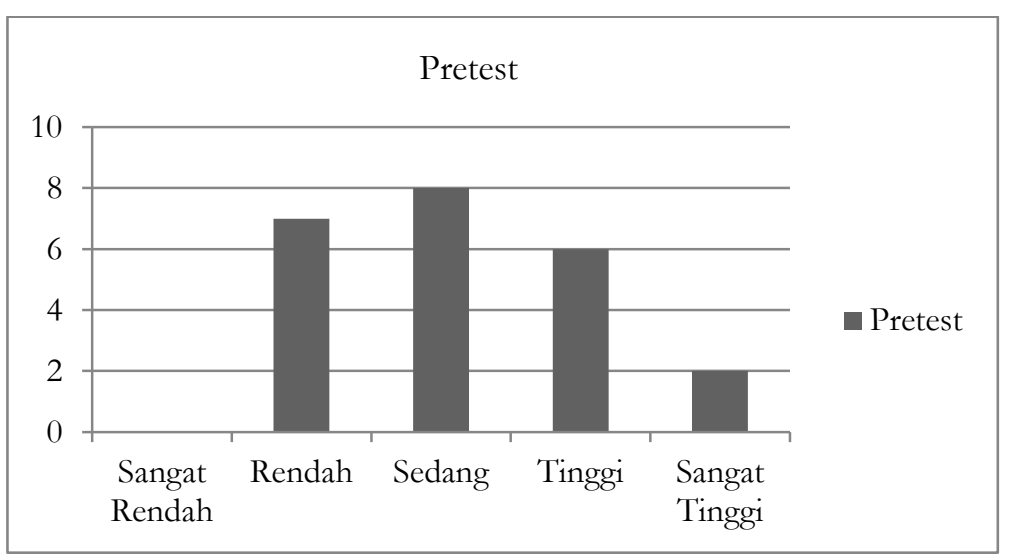

Gambar 1. Diagram Batang Hasil rata-rata pemahaman Siswa mengenai bahaya seks bebas.

Dari tabel 1 menunjukakan bahwa, data dari hasil pretest 23 orang siswa, yang dijadikan sampel penelitian ada 7 orang responden memiliki pemahaman Siswa mengenai bahaya seks bebas yang rendah dengan persentase 30.43\%, Salanjutnya 8 orang responden memiliki pemahaman Siswa mengenai bahaya seks bebas sedang 34.79\%, dan seterusnya 6 orang responden memiliki pemahaman siswa mengenai bahaya sek bebas Tinggi dengan persentase $26.08 \%$. dan seterusnya 2 orang responden yang memiliki pemahaman Siswa mengenai bahaya seks bebas sangat tinggi dengan persentase $8.7 \%$, Jadi dapat disimpulkan dari tabel 5 bahwa rata-rata pemahaman Siswa mengenai bahaya seks bebas berada pada kategori sedang. Hal ini dibuktikan dari hasil perolehan responden yaitu $62 \%$.

\section{Deskripsi Data Posttest}

Setelah pemberian perlakuan berupa layanan informasi dengan mengunakan Strategi Cooperative Learning sebanyak 6 kali pada siswa, kemudian peneliti mengukur bagaimana 
pemahaman Siswa mengenai bahaya seks bebas sesudah diberikan perlakuan. Data Hasil Posttest akan dijabarkan pada tabel berikut ini:

Tabel 2. Data Hasil Posttest Pemahaman Siswa Mengenai Bahaya Seks Bebas

\begin{tabular}{|c|c|c|c|}
\hline Kategori & Rentang Skor & Frekuensi & Persentase \\
\hline Sangat Rendah & $\leq 42$ & 0 & 0 \\
\hline Rendah & $42>$ s.d $\leq 56$ & 0 & 0 \\
\hline Sedang & $56>$ s.d $\leq 69$ & 0 & 0 \\
\hline Tinggi & $69>$ s.d $\leq 83$ & 10 & 43.48 \\
\hline Sangat Tinggi & $83>$ & 13 & 56.52 \\
\hline \multicolumn{2}{|c|}{ Jumlah } & 23 & 100 \\
\hline
\end{tabular}

Selanjutnya, pemahaman Siswa mengenai bahaya seks bebas masing-masing siswa dari hasil posttest dapat dijelaskan pada diagram sebagai berikut.

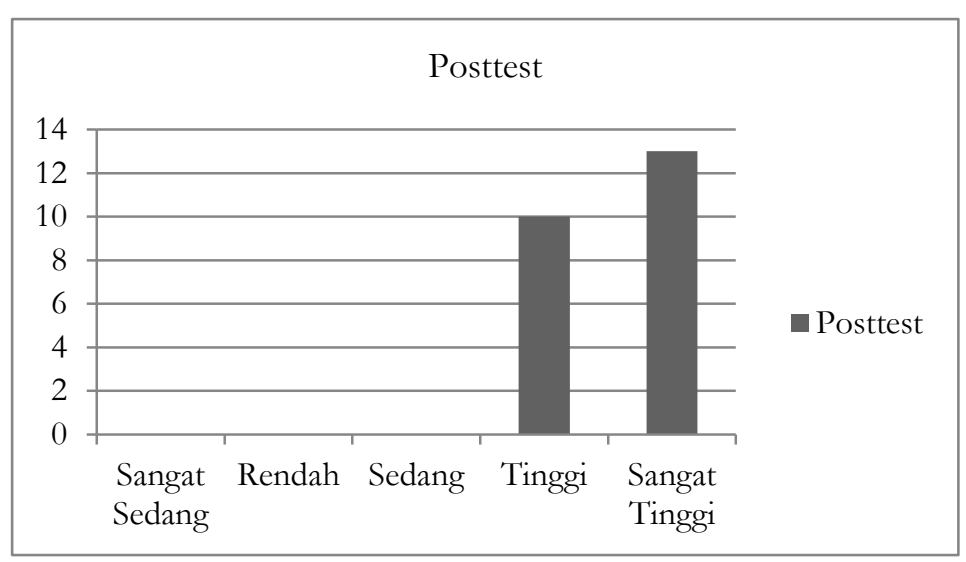

Gambar 2. Diagram Batang Hasil Posttest pemahaman Siswa mengenai bahaya seks bebas.

Data dari tabel 3 dan diagram diatas menunjukakan bahwa hasil posttest pada 23 orang siswa yang memiliki pemahaman Siswa mengenai bahaya seks bebas dapat dilihat ada 10 orang pemahaman Siswa mengenai bahaya seks bebas tinggi dengan persentase $43.48 \%$, Salanjutnya 13 orang responden memiliki pemahaman Siswa mengenai bahaya seks bebas sangat tinggi dengan persentase $56.52 \%$.

Berdasarkan data yang diperoleh, maka rata-rata skor Posttest yang diperoleh pada variabel pemahaman Siswa mengenai bahaya seks bebas sebesar 87\%. Maka dapat disimpulkan bahwa secara keseluruhan hasil posttest rata-rata skor pemahaman Siswa mengenai bahaya seks bebas berada pada kategori Sangat tinggi. Hal ini berarti bahwa rata-rata skor pemahaman Siswa mengenai bahaya seks bebas antara pretest dan posttest berada pada kategori yang berbeda sehingga dapat dikatakan bahwa pemahaman Siswa mengenai bahaya seks bebas mengalami peningkatan yang signifikan. 


\section{Perbedaan Pretest dan Posttest}

Perbedaan pemahaman Siswa mengenai bahaya seks bebas dimiliki siswa dapat dilihat pada kegiatan eksperimen dari hasil pretest dan posttest yang dapat dijelaskan pada tabel sebagai berikut:

Tabel 3. Perbandingan Kondisi pemahaman Siswa mengenai bahaya seks bebas pada saat pretest dan posttest

\begin{tabular}{llcccc}
\hline No & Kode & Pretest & \multicolumn{2}{l}{ Posttest } & \\
\cline { 2 - 6 } & Siswa & Skor & Kategori & Skor & Kategori \\
\hline 1 & AK & 72 & Sedang & 91 & Sangat Tinggi \\
\hline 2 & AF & 58 & Rendah & 75 & Sedang \\
\hline 3 & AS & 57 & Rendah & 92 & Sangat Tinggi \\
\hline 4 & AN & 68 & Sedang & 89 & Tinggi \\
\hline 5 & AD & 88 & Tinggi & 107 & Sangat Tinggi \\
\hline 6 & CAK & 65 & Rendah & 87 & Tinggi \\
\hline 7 & CN & 50 & Sangat Rendah & 76 & Sedang \\
\hline 8 & FA & 61 & Sedang & 86 & Tinggi \\
\hline 9 & FS & 65 & Rendah & 90 & Tinggi \\
\hline 10 & FH & 54 & Rendah & 80 & Sedang \\
\hline 11 & GI & 53 & Sangat Rendah & 78 & Sedang \\
\hline 12 & HZ & 50 & Sangat Rendah & 81 & Sedang \\
\hline 13 & IP & 44 & Rendah & 86 & Tinggi \\
\hline 14 & LS & 73 & Sedang & 90 & Tinggi \\
\hline 15 & LDA & 65 & Sangat Rendah & 76 & Sedang \\
\hline 16 & MD & 71 & Sedang & 82 & Sedang \\
\hline 17 & RMN & 45 & Sangat Rendah & 78 & Sedang \\
\hline 18 & RAP & 66 & Rendah & 106 & Sangat Tinggi \\
\hline 19 & SS & 70 & Rendah & 85 & Sedang \\
\hline 20 & VDV & 45 & Sangat Rendah & 77 & Sedang \\
\hline 21 & VS & 93 & Tinggi & 106 & Sangat Tinggi \\
\hline 22 & NI & 82 & Sedang & 108 & Sangat Tinggi \\
\hline 23 & ZK & 43 & Sangat Rendah & 80 & Sedang \\
\hline & & & & \\
\hline
\end{tabular}

Berdasarkan tabel 3 diatas dapat diketahui bahwa terdapat perbedaan kondisi pemahaman Siswa mengenai bahaya seks bebas kelas VIII sebelum dan sesudah diberikan perlakuan berupa Layanan Informasi dengan mengunakan Strategi Cooperative Learning. Siswa yang pada saat pretest memiliki rata-rata 63\% setelah diberi perlakuan, skor rata-rata menjadi $87 \%$. Berdasarkan hal ini, terjadi peningkatan pemahaman Siswa mengenai bahaya seks bebas $24 \%$ setelah diberi perlakuan.

Dari uraian sebelumnya dapat diketahui bahwa terdapat perbedaan pemahaman Siswa mengenai bahaya seks bebas sebelum dan sesudah diberi perlakuan berupa Layanan Informasi dengan mengunakan Strategi Cooperative Learning. Dari 23 orang siswa yang mendapat perlakuan, secara keseluruhan pemahaman Siswa mengenai bahaya seks bebas semakin meningkat. Hal ini bisa dilihat dari meningkatnya skor secara keseluruhan dengan rata-rata 
$87 \%$ siswa mengalami peningkatan skor pemahaman Siswa mengenai bahaya seks bebas. Berdasarkan tabel data hasil pretes dan posttest pemahaman Siswa mengenai bahaya seks bebas pada siswa.

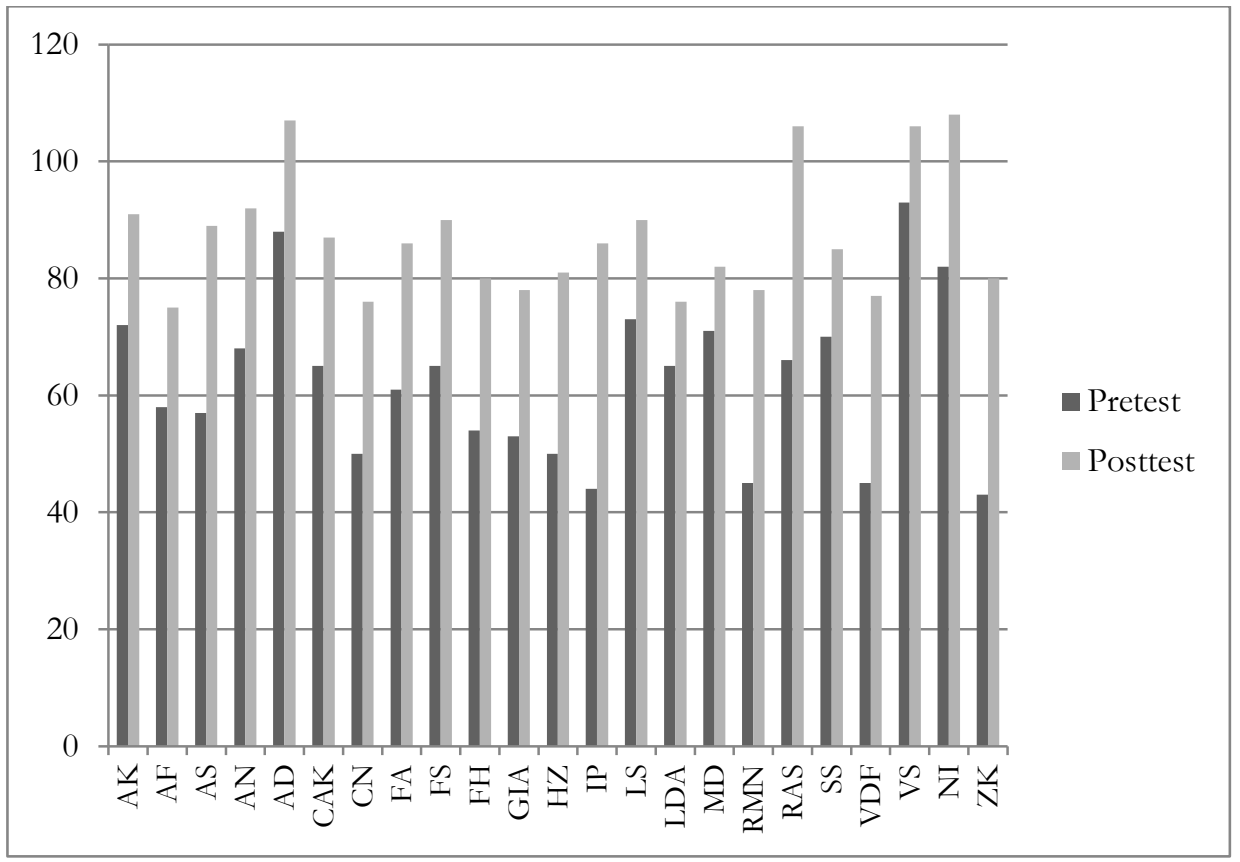

Gambar 3. Diagram Batang Hasil Pretest dan Posttest Pemahaman Siswa Mengenai Bahaya Seks Bebas

Berdasarkan Gambar 3 diketahui bahwa terdapat perbedaan pemahaman Siswa mengenai bahaya seks bebas kepada siswa sebelum diberikan perlakuan (Pretest) dan sesudah diberikan perlakuan (Posttest) berupa Layanan Informasi dengan mengunakan Strategi Cooperative Learning 62\%. setelah diberi perlakuan menjadi berada pada rata-rata 87\%, Berdasarkan hal ini terjadi peningkatan pemahaman Siswa mengenai bahaya seks bebas sebanyak $24 \%$.

\section{Pengujian Hipotesis}

Untuk menguji hipotesis digunakan uj Wilcoxon Signed Rank dengan menggunakan SPSS. Uji Wilcoxon digunakan untuk menganalisis hasil-hasil pengamatan yang berpasangan dari dua data apakah berbeda atau tidak. Adapun hasil perhitungannya dapat dilihat pada tabel berikut: 
Tabel 4. Hasil analisis Wilcoxon Signed Rank Test Perbedaan pemahaman terhadap bahaya seks bebas antara Pretest dan Posttest

\begin{tabular}{lr}
\hline & PostTest - Pre'Test \\
\hline$Z$ & $-4.200^{\mathrm{a}}$ \\
\hline Asymp. Sig. (2-tailed) & .000 \\
\hline
\end{tabular}

Berdasarkan tabel di atas dapat dilihat bahwa nilai asymp.Sig (2-tailed) sebesar 0,000. Berdasarkan analisis tersebut diketahui bahwa $0,000<0.05$ dengan demikian dapat disimpulkan bahwa terdapat perbedaan pretest dan posttest.

pemahaman terhadap bahaya seks bebas pada siswa diberikan perlakuan berupa layanan informasi dengan menggunakan strategi cooperative learning.

\section{PEMBAHASAN}

Sekolah merupakan tempat dimana siswa dapat mengembangkan pemahaman yang positif maupun negatif, salah satunya mengenai bahaya seks bebas. Melalui pemahaman yang baik mengenai bahaya seks bebas,diharapkan siswa dapat memilih pergaulan yang positif, menjauhi seks bebas, lebih mendekatkan diri dengan Allah, Mengatahui bahaya dari seks bebas dan Meningkatkan kepercayaan diri sehingga ia mampu untuk melakukan aktivitas sehari-hari. Adapun temuan penelitian ini adalah terdapat perbedaan pemahaman Siswa mengenai bahaya seks bebas sebelum diberikan perlakuan (pretest) dan sesudah diberikan perlakuan (posttest) berupa layanan informasi dengan mengunakan strategi cooperative learning

Berdasarkan hasil penelitian tersebut maka dapat dipahami bahwa Penerapan Layanan Informasi dengan Mengunakan Strategi Cooperative Learning untuk Meningkatkan Pemahaman SiswaMengenai Bahaya Seks Bebas. Layanan informasi yang diperoleh individu sangat diperlukan agar individu lebih mudah membuat perencanaan dan mengambil keputusan dan meningkatkan pemahaman (Nurihsan, 2009). Cooperative Learning yang artinya memaksimalkan belajar siswa untuk meningkatkan akademik dan pemahaman baik secara individu maupun kelompok serta saling membantu satu sama lain (Syarifuddin, 2011). Dengan demikian maka penulis simpulkan bahwa Penerapan Layanan Informasi Dengan Mengunakan Strategi Cooperative Learning dapat Meningkatkan Pemahaman Siswa mengenai bahaya seks bebas.

Beberapa hasil penelitian juga telah membuktikan teori tersebut. Putri, dan Sutijono, melakukan penelitian dengan judul Penerapan Bimbingan Kelompok Teknik Home Room untuk Meningkatkan Pemahaman Siswa pada siswa kelas XI ISI SMA N I Mojokerto Tentang Bahaya Seks Bebasdalam pemberian angket pre-test ditemukan 7 siswa yang memiliki skor 
terendah. Dari 7 siswa tersebut di berikan perlakuan dengan menggunakan bimbingan kelompok teknik home room untuk membantu siswa meningkatkan pemahaman tentang bahaya seks bebas.

Dari hasil analisis data dapat diketahui bahwa ada perbedaan skor antara sebelum dan sesudah penerapan bimbingan kelompok dengan teknik home room untuk meningkatkan pemahaman siswa terhadap bahaya seks bebas (Putri \& Sutijono, 2013).

Begitu pula dengan penelitian yang dilakukan oleh Al Amin (2016) yang berjudul "Upaya Meningkatkan Pemahaman Bahaya Seks Bebas Melalui Layanan Informasi Berbantuan Audio Visual Pada Siswa Kelas X Pd 1 SMK Raden Umar Said Kudus" Berdasarkan hasil pembahasan dan analisis data dapat disimpulkan layanan informasi dengan media audio visual dapat meningkatkan pemahaman bahaya seks bebas kelas X PD 1 SMK Raden Umar Said Kudus 2014/2015. Hasil penelitian pra siklus rata-rata 48\% siklus 1 rata-rata 56\% dan siklus 2 rata-rata $76 \%$ jadi peningkatanya $20 \%$.

Selanjutnya dengan penelitian yang dilakukan oleh Nurhidayati \& Pratiwi (2013) yang berjudul "Pengembangan Media Video Untuk Meningkatkan Pemahaman Bahaya Seks Bebas Di Kalangan Remaja SMA Negeri 1 Soko Tuban" media video ini layak digunakan sebagai media yang dapat menunjang layanan bimbingan dan konseling, khususnya untuk meningkatkan pemahaman tentang bahaya seks bebas di kalangan remaja secara lebih efektif dan efisien. Hasil uji kelayakan permainan oleh ahli media sebesar 84,5\% dengan keterangan layak.

\section{SIMPULAN}

Berdasarkan hasil penelitian yang diperoleh, maka dapat disimpulkan secara umum bahwa Penerapan Layanan Informasidengan Mengunakan Strategi Cooperative Learning untuk Meningkatkan Pemahaman siswa mengenai bahaya seks bebas. Secara khusus antara lain : 1) gambaran Pemahaman Siswa Mengenai Bahaya Seks Bebas sebelum diberi perlakuan berada pada kategori Sedang; 2) pemahaman SiswaMengenai Bahaya Seks Bebas setelah diberi perlakuan berada pada kategori Sangat tinggi; dam 3) terdapat peningkatan pemahaman siswa mengenai bahaya seks bebas setelah diberikan perlakuan berupa Layanan Informasi dengan Mengunakan Strategi Cooperative Learning. 


\section{REFERENSI}

Amin, Zuli Al. (2015). Upaya Meningkatkan Pemahaman Bahaya Seks Bebas Melalui Layanan Informasi Berbentuk Audio Visual pada Siswa Kelas X pada 1 SMK Raden Umar Said Kudus. Skripsi tidak diterbitkan. Kudus: Program Studi Bimbingan dan Konseling Fakultas Keguruan dan Ilmu Pendidikan Universitas Muria Kudus.

Azwar, Saifuddin. (2010). Penyusunan Skala Psikologi. Yogyakarta : Pustaka Pelajar

Hallen. A, (2005). Bimbingan dan Konseling. Jakarta : Quantum Teaching

Hayati, I., \& Sujadi, E. (2018). Perbedaan Keterampilan Belajar Antara Siswa IPA dan IPS. Tarbawi : Jurnal Ilmu Pendidikan, 14(1), 1-10. doi:10.32939/tarbawi.v14i1.250

Huda, Syamsul, et al. (2010). Faktor yang mempengaruhi Perilaku Seks Pranikah Mahasiswa di Pekalongan Tahun 2009-2010. Jurnal Kesehatan Repoduksi, 1 (1) 33-41.

Margonos, S. (2009). Metodologi Penelitian Pendidikan, Jakarta : Rineka Cipta

Nurhidayati, Devi \& Pratiwi, Titin Indah. (2013). Pengembangan Media Video untuk Meningkatkan Pemahaman Bahaya Seks Bebas di Kalangan Remaja SMA Negeri 1 Soko Tuban. Jurnal BK UNESA, 3 (1): 281.

Nurihsan, Achmad Juntika. (2009). Bimbingan dan Konseling. Bandung: PT Refika.

Prayitno \& Amti, Erman. (2004). Dasar-dasar bimbingan dan konseling. Jakarta: PT Rineka Cipta

Putri, Ghea Gendys Renjana, et al. (2016). Penerapan Bimbingan Kelompok Teknik Homo Untuk Meningkatkean Pemahaman bahaya seks bebas bagi siswa. Journal Bimbingan Konseling, 1 (1): 79

Rofiq, M. Nafiur. (2010). Pembelajaran Kooperatif (Cooperative Learning). Jurnal Falasifa, 1 (1).

Sari, Erlina. (2017). Penerapan Strategi Cooperative Learning untuk meningkatkan Etika Pergaulan Siswa. Jurnal Al-irsyad, 8 (1).

Sugiyono. (2016). Metode Penelitian Kuantitatif, kualitiataf dan R\&D, Bandung: Alfabeta (2011). Metode Penelitian Kuantitatif, Kualitatif dan R\&d, Bandung : Alfabeta

Sujadi, E. (2017). Penerapan Pendidikan Karakter Cerdas Format Kelompok untuk Meningkatkan Nilai Kejujuran Mahasiswa Bimbingan Konseling Islam (BKI) Institut Agama Islam Negeri (IAIN) Kerinci. Tarbawi : Jurnal Ilmu Pendidikan, 13(1), 97-108

Sujadi, E., \& Wahab, M. (2018). Strategi Coping Korban Bullying. Tarbawi : Jurnal Ilmu Pendidikan, 13(2), 21-32.

Sujadi, E. (2018). Kode Etik Profesi Konseling Serta Permasalahan dalam Penerapannya. Tarbawi: Jurnal Ilmu Pendidikan, 14 (2), 69-77. doi:10.32939/tarbawi.v14i2.298 
Sujadi, E., Ayumi, RT., Indra, S., Sumarto., Rahima, R. (2018). Layanan Konseling Kelompok dengan Menggunakan Pendekatan Cognitive Behavioral untuk Membentuk Internal Locus of Control. Jurnal Fokus Konseling, 4 (2), 176-184.

Sukardi, Dewa Ketut. (2008). Pengantar Pelaksana Program Bimbingan dan Konseling di Sekolah. Jakarta: PT Rineka Cipta.

Supriyono, Agus. (2009). Cooperative Learning. Surabaya : Pustaka Pelajar

Syarifuddin, A. Model Pembelajaran Cooperative Learning Tipe Jigsaw dalam Pembelajaran. Ta'dib: Journal of Islamic Education (Jurnal Pendidikan Islam), 16 (02), 209226.

Yusuf, A. Muri. (2003). Metode Penelitian Kuantitatif, Kualitatif dan Penelitian Gabungan. Padang: UNP Press. 